Research Article

\title{
Astyanax hastatus Myers, 1928 (Teleostei, Characidae): A new species complex within the genus Astyanax?
}

\author{
Karine Frehner Kavalco ${ }^{1}$, Karina de Oliveira Brandão ${ }^{2}$, Rubens Pazza $^{1}$ \\ and Lurdes Foresti de Almeida-Toledo ${ }^{2}$ \\ ${ }^{1}$ Universidade Federal de Viçosa, Campus de Rio Paranaiba, Rio Paranaiba, MG, Brazil. \\ ${ }^{2}$ Departamento de Genética e Biologia Evolutiva, Instituto de Biociências, \\ Universidade de São Paulo, São Paulo, SP, Brazil.
}

\begin{abstract}
Four populations of Astyanax hastatus Myers 1928 from the Guapimirim River basin (Rio de Janeiro State) were analyzed and three distinct cytotypes identified. These cytotypes presented $2 \mathrm{n}=50$ chromosomes, with $4 \mathrm{M}+8 \mathrm{SM}+10 \mathrm{ST}+28 \mathrm{~A}$ (Cytotype A), 8M+10SM+14ST+18A (Cytotype B), 6M+8SM+4ST+32A (Cytotype C) and scanty heterochromatin, mainly located throughout pericentromeric regions of several chromosomal pairs. No homologies with the As-51 satellite DNA were observed in the three cytotypes, although all of them presented multiple $18 \mathrm{~S}$ rDNA sites, as detected by both silver nitrate staining and FISH (fluorescent in situ hybridization). The application of the term "species complex" in Astyanax is discussed from a cytotaxonomic viewpoint.
\end{abstract}

Key words: Astyanax hastatus, molecular cytogenetics, karyotypic evolution, species complex.

Received: August 8, 2008; Accepted: December 2, 2008.

\section{Introduction}

Characins comprise many species of small fishes of the genus Astyanax. They are widespread from the southern United States down to north Argentina (Eigenmann, 1921). This Neotropical genus is composed of nearly 90 valid species, mostly found in small bodies of water.

The data available in the literature indicate that the modal chromosomal number for the genus Astyanax is $2 \mathrm{n}=50$ chromosomes, although a wide variation in chromosomal constitution has often been reported. Probably, non-Robertsonian re-arrangements, such as pericentric inversions, have played a key role in the chromosomal diversity of this genus (Pazza and Kavalco, 2007).

Based on chromosomal features, three "species complexes" have been identified within Astyanax (Moreira-Filho and Bertollo, 1991; Fernandes and Martins-Santos, 2004; Pazza et al., 2006). Despite the absence of distinguishable morphological traits within the previously mentioned Astyanax groups, differences in the chromosomal number and karyotype formulae, apart from other macrostructural features, are easily identified among distinct cytotypes.

Moreira-Filho and Bertollo (1991) reported karyotypic variation in populations of "A. scabripinnis", comprised of variations in the diploid number $(2 n=46,48$ or 50

Send correspondence to Karine Frehner Kavalco. Campus Rio Paranaíba, Universidade Federal de Viçosa. Rodovia BR $354 \mathrm{~km}$ 310, 38810-000 Rio Paranaíba, MG, Brazil. E-mail: kavalco@biociencia.org. chromosomes) and in the pattern of constitutive heterochromatin distribution. Based on these data, the authors concluded that distinct karyotypes could correspond to unique evolutionary units, since each cytotype probably arose from allopatric speciation processes.

The group "A. fasciatus" presented high karyotypic diversity. Two "standard" cytotypes were characterized by the exclusive presence of homologous chromosomes (bearing $2 n=46$ and $2 n=48$ ). However, other variant cytotypes were also detected with $2 n=45$ and $2 n=46$, besides several types with $2 n=47$, all co-existing under sympatric and syntonic conditions, whereat not all the chromosomes presented their counterparts. In this case, inter-cytotypic hybridization was considered as a probable hypothesis for explaining the occurrence of variant karyotypes (Pazza et al., 2006). Although a certain degree of gene flow was present among the cytotypes, readily detectable hybrids were not found, thereby indicating the occurrence of incipient divergence within the group (Pazza et al., 2007).

These "species complexes" are characterized by wide cytogenetic variation, mainly regarding distinct chromosomal numbers. However, the differences between karyotypes could also be restricted to karyotype formulae, or in other words, the karyotypes might present different chromosomal types, thereby suggesting the occurrence of nonRobertsonian re-arrangements. For instance, " $A$. altiparanae" represents another quite variable group, in which FN (fundamental number) values in the reported 
cytotypes range from 76 to 100 , whereas the diploid number $(2 n=50)$ remains the same (Fernandes and MartinsSantos, 2004).

In the present work, we present cytogenetic data regarding distinct populations of Astyanax hastatus, a species where all prior information on karyotypes is lacking. The analyzed specimens were collected in four different sites along the Guapimirim River basin (State of Rio de Janeiro) (Figure 1). Chromosomal studies involving conventional and molecular techniques were undertaken with a view to increasing current knowledge on the chromosomal evolutionary pathways in this species-rich genus. The "species complex" concept and its application to the set of distinct cytotypes of $A$. hastatus and other Astyanax species that also present closely related cytogenetic variant forms, are discussed.

\section{Material and Methods}

Specimens of A. hastatus from four distinct localities (Table 1, Figure 1) along the Guapimirim River basin, a part of the Coastal River Basin, at Serra dos Orgãos, Rio de Janeiro, Brazil, were analyzed. The sampled specimens reached up to $10 \mathrm{~cm}$ in standard length, although individuals of less than $3 \mathrm{~cm}$ in length were more frequent. All specimens were identified and deposited in the collection of the Museum of UFRGS and MCT (PUC-RS), Brazil.

The mitotic chromosomes were obtained according to Gold et al. (1990). Silver nitrate staining (Ag-NOR) was done according to Kavalco and Pazza (2004). C-banding followed the procedure as described by Sumner (1972). Fluorescent in situ hybridization (FISH) (Pinkel et al., 1986; Pazza et al., 2006) was performed by using $18 \mathrm{~S}$ rDNA probes (Hatanaka and Galetti Jr, 2004) and a satellite DNA probe (As-51) isolated from A. scabripinnis (Mestriner et al., 2000).

Chromosomal preparations were analyzed under a light microscope and the images (resolution of 5Mp) were captured using the image analysis system CoolSnap Pro and the software Image Pro Plus (Media Cybernetics). The classification of chromosomal types was based on the arm ratio (AR), as follows: M-metacentric ( $\mathrm{AR}=1.00-1.70)$, SM-submetacentric $(\mathrm{AR}=1.71-3.00), \mathrm{ST}$-subtelocentric

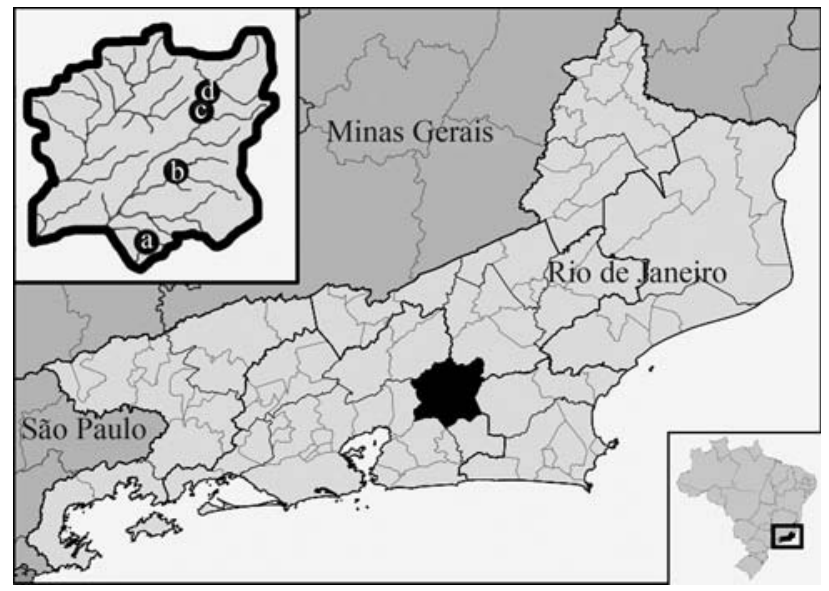

Figure 1 - Map showing four different sites along the Guapimirim river basin, in the State of Rio de Janeiro, Brazil. In the large box, the area of Cachoeiras de Macacu county indicating sampling sites: (a) Ypiranga community; (b) Santana de Japuíba county; (c) Macacu river and (d) the town of Cachoeiras de Macacu.

$(\mathrm{AR}=3.01-7.00)$ and A-acrocentric (AR higher than 7.00), according to Levan et al. (1964).

\section{Results}

All of the populations presented the same chromosomal number, Ag-NORs and 18S rDNA sites on the short arms of ST-A chromosomes and a similar pattern of heterochromatin distribution. Nevertheless, distinct karyotypic formulae were observed, with the identification of three different cytotypes.

The specimens from site (a) presented $2 \mathrm{n}=50$ chromosomes with a karyotype formula composed of $4 \mathrm{M}+8 \mathrm{SM}+10 \mathrm{ST}+28 \mathrm{~A}$ and $\mathrm{FN}=72$ (cytotype $\mathrm{A}$ ) (Figure $2 \mathrm{a})$. The specimens from site (b) presented $2 \mathrm{n}=50$ chromosomes distributed into $8 \mathrm{M}+10 \mathrm{SM}+14 \mathrm{ST}+18 \mathrm{~A}$, with $\mathrm{FN}=82$ (cytotype B) (Figure 2b). Specimens from sites (c) and (d) shared a common cytotype, with $2 \mathrm{n}=50$ chromosomes arranged into $6 \mathrm{M}+8 \mathrm{SM}+4 \mathrm{ST}+32 \mathrm{~A}$, and $\mathrm{FN}=68$ (cytotype C) (Figure 2c).

Cytotype A presented three Ag-NOR bearing chromosomes (Figure $2 \mathrm{a}$ - box), while six signals were identi-

Table 1 - Sample analyzed.

\begin{tabular}{|c|c|c|c|c|c|c|c|}
\hline Locality & Collection number & GPS & $\mathrm{N}$ & $\mathrm{F}$ & M & $\mathrm{U}$ & Map \\
\hline Ypiranga community & UFRGS 10.257 & $\begin{array}{l}\text { S } 22^{\circ} 38^{\prime} 11.6^{\prime \prime} \\
\text { Wo } 42^{\circ} 42^{\prime} 42.3^{\prime \prime}\end{array}$ & 22 & 8 & 9 & 5 & $\mathrm{a}$ \\
\hline Santana de Japuíba county & UFRGS 10.258 & $\begin{array}{c}\text { S } 22^{\circ} 33^{\prime} 39.9^{\prime \prime} \\
\text { Wo } 42^{\circ} 40^{\prime} 51.1^{\prime \prime}\end{array}$ & 10 & 2 & 3 & 5 & $\mathrm{~b}$ \\
\hline Macacu river & UFRGS 10.259 & $\begin{array}{c}\text { S } 22^{\circ} 29^{\prime} 06.1^{\prime \prime} \\
\text { Wo } 42^{\circ} 39^{\prime} 40.3^{\prime \prime}\end{array}$ & 27 & 1 & 1 & 25 & $\mathrm{c}$ \\
\hline Cachoeiras de Macacu city & MCT 43.285 & $\begin{array}{l}\text { S } 22^{\circ} 27^{\prime} 51.2^{\prime \prime} \\
\text { Wo } 42^{\circ} 39^{\prime} 16.5^{\prime \prime}\end{array}$ & 15 & 9 & 5 & 1 & $\mathrm{~d}$ \\
\hline
\end{tabular}

$\mathrm{N}$ : number of analyzed specimens; F: females; M: males; U: undetermined sex. 
fied at the terminal position of A chromosomes by 18S-FISH (Figure 3d). In the same way, cytotype B presented three Ag-NOR bearing sites (Figure $2 b-$ box), although only four signals on the short arms of A chromosomes were observed by $18 \mathrm{~S}-\mathrm{FISH}$, besides a pair bearing bitelomeric marks (Figure 3e). Cytotype C presented a variable number of silver nitrate marks, ranging from one to eight sites, with a predominance of two active NORs (Figure 2c-box). After 18S-FISH, four ribosomal DNA regions were identified at the terminal position of A chro-

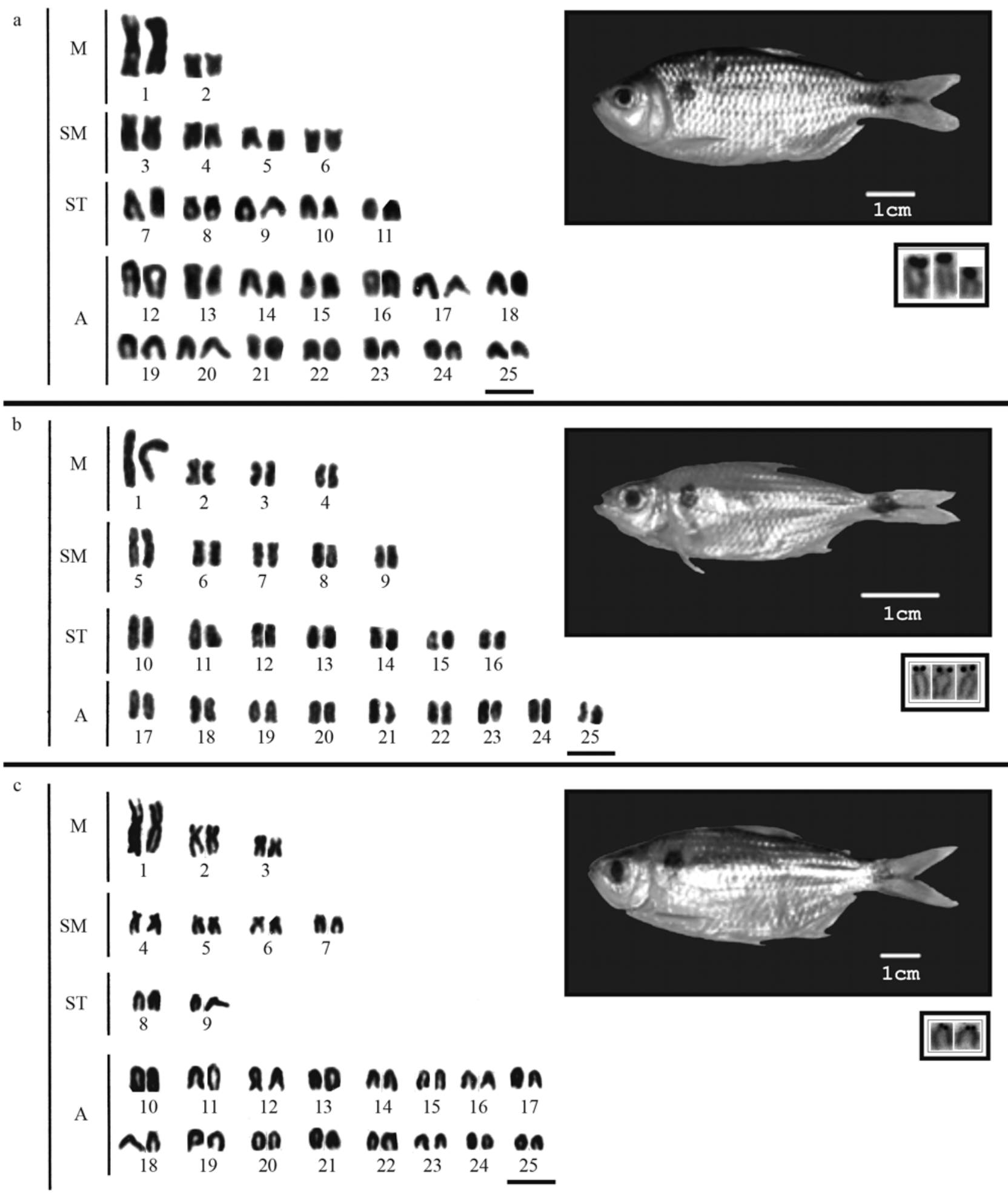

Figure 2 - Karyotypes and specimens of cytotypes A (a), B (b) and C (c) of Astyanax hastatus. The respective Ag-NORs, are shown in the boxes. Bars $=5 \mu \mathrm{ms}$. 
mosomes, plus a SM chromosomal pair bearing terminal marks on short arms (Figure 3f).

C-banding revealed few heterochromatic segments, mainly located at the pericentromeric region of chromosomes in all cytotypes (Figure 3a, b, c). No positive signals were detected after hybridization with As-51 satellite DNA probes (Figure 3g, h, i).

\section{Discussion}

The genus Astyanax is characterized by remarkable karyotypic diversity (Pazza and Kavalco, 2007) and, according to Langecker et al. (1991) and Jeffery (2001), this group stands out as an excellent model for all kinds of studies on evolutionary mechanisms. In relation to Neotropical fish fauna, the genus Astyanax can be regarded as one of the best documented groups from a cytogenetic standpoint, with more than 60 published reports on different species. In this context, the groups A. scabripinnis, A. altiparanae (sometimes referred to as $A$. bimaculatus) and $A$. fasciatus are those that present by far the highest number of analyzed populations (for a review, see Pazza and Kavalco, 2007).

Karyotypic diversity in the genus Astyanax might involve diploid number and karyotypic macrostructure, the presence or absence of B chromosomes, heterochromatin a

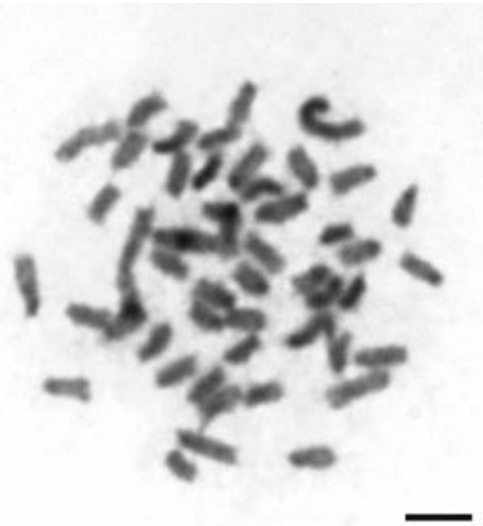

b

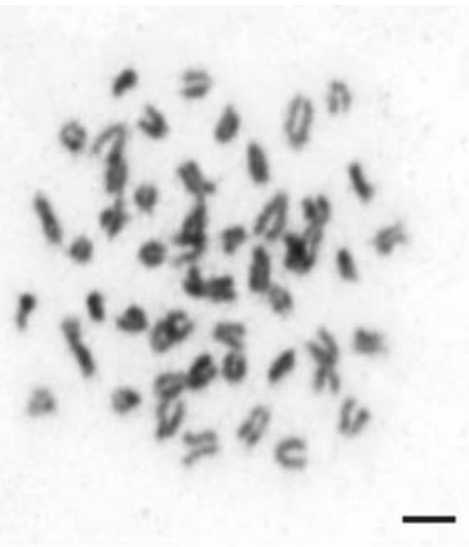

c

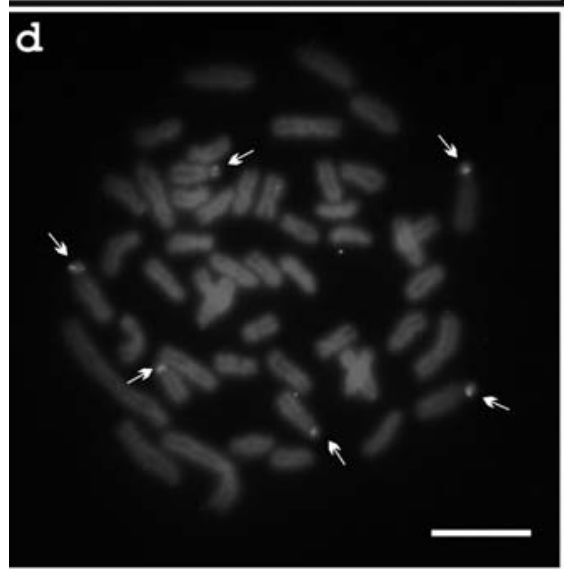

g
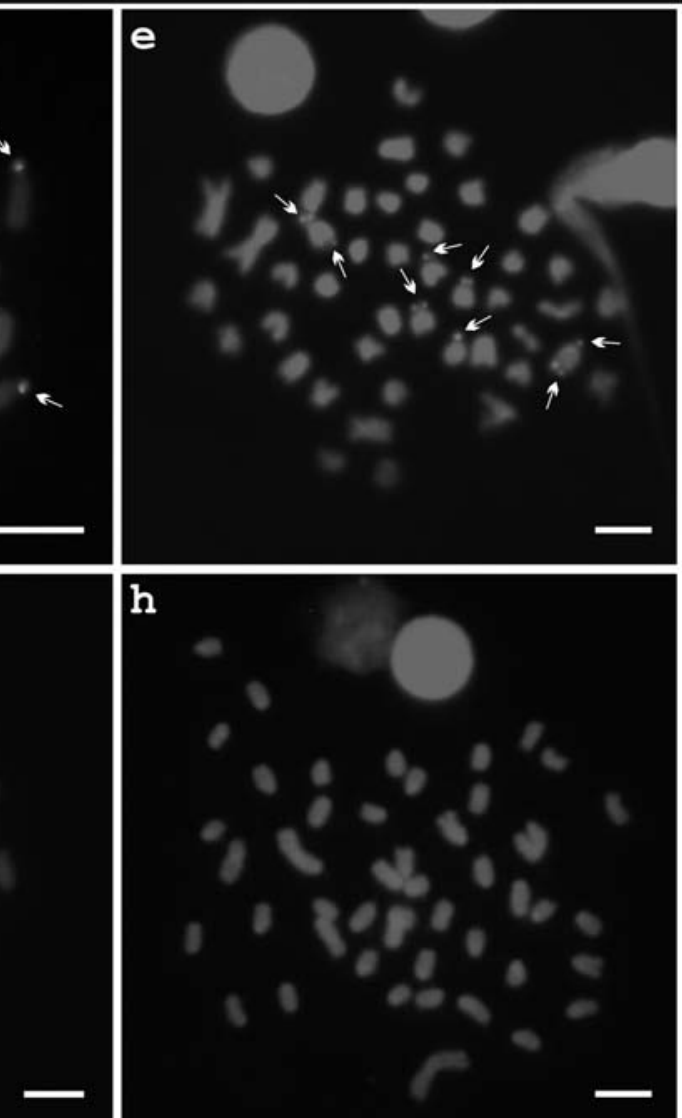

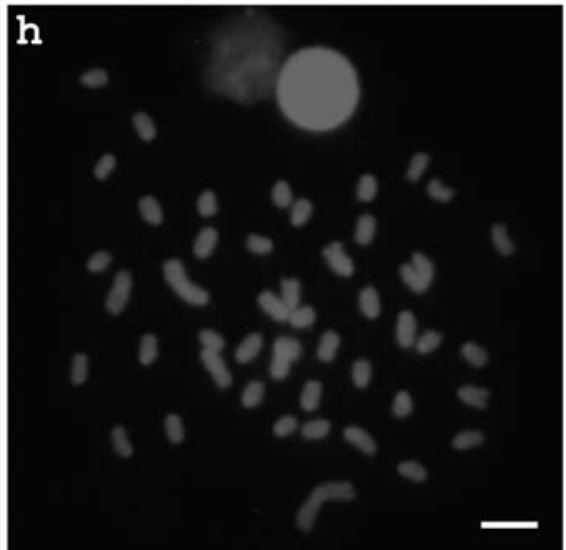

h

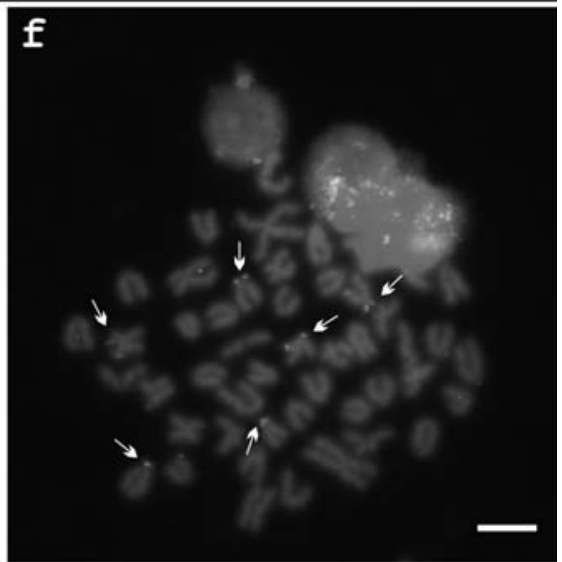

i

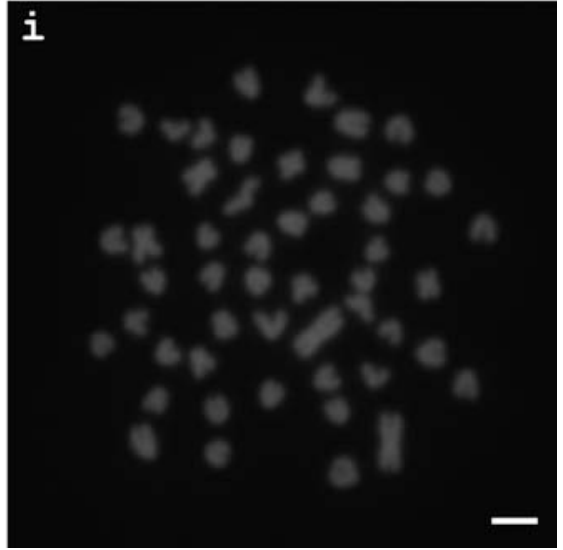

Figure 3 - Metaphases of Astyanax hastatus. Cytotypes A, B and C after C-banding (a-c), and FISH with rDNA 18S (d-f) and satellite DNA As-51 (g-i) probes. The arrows indicate rDNA sites. Bars $=5 \mu \mathrm{m}$. 
polymorphism and the differential location of ribosomal sites. Due to such variability, often detected at inter- and intra-population levels, the occurrence of "species complexes" has been suggested for at least three groups within the genus (Moreira-Filho and Bertollo, 1991; Justi AJ, MSc Dissertation, Universidade Federal de São Carlos, UFSCar, Brazil.1993; Fernandes and Martins-Santos, 2004).

A. hastatus shares some of the features observed in the A. altiparanae species complex, such as a conserved diploid number $(2 \mathrm{n}=50$ chromosomes), distinct karyotypic formulae and FN values (Figure 2), as well as the variable number and position of ribosomal genes. This type of variation seems to indicate that certain evolutionary processes such as pericentric and paracentric inversions might have played a key role in the chromosomal differentiation of populations of $A$. hastatus.

The ancestral karyotype within the genus Astyanax was most probably composed of $2 \mathrm{n}=50$ chromosomes (6M, 22SM, 10ST and 12A), since it is found at the base of neighbor-joining dendrograms based on karyotypic traits of distinct species/populations from this genus (Pazza and Kavalco, 2007). In effect, although some species of the genus Astyanax might present distinctive diploid numbers other than 50 chromosomes, as, for example, A. schubarti $(2 \mathrm{n}=36)($ Daniel-Silva and Almeida-Toledo, 2005) and some populations of $A$. scabripinnis and A. fasciatus, which bear $2 \mathrm{n}=46$ and $2 \mathrm{n}=48$ chromosomes, respectively (Moreira-Filho and Bertollo, 1991; Justi AJ, MSc Dissertation, Universidade Federal de São Carlos, UFSCar, Brazil, 1993; Pazza et al., 2006), the vast majority of the studied species do indeed present $2 \mathrm{n}=50$ chromosomes (Pazza and Kavalco, 2007).

Another feature of the genus is the presence of multiple cistrons of $18 \mathrm{~S}$ rDNA. The 18S rDNA sites in Astyanax are rather dispersed throughout the karyotype, and can range either among populations of a single species or among species of a same group (Mantovani et al., 2005), exactly as observed in $A$. hastatus (Figure $3 \mathrm{~d}-\mathrm{f}$ ). They are usually observed at terminal regions of chromosomes (Ferro et al., 2001; Almeida-Toledo et al., 2002; Kavalco and Moreira-Filho, 2003; Mantovani et al., 2005; Pazza et al., 2006), or in an interstitial position (Almeida-Toledo et al., 2002), and due to their reduced size, a precise determination of rDNA location and number is commonly thwarted (Ferro et al., 2001; Kavalco and Moreira-Filho, 2003; Pazza et al., 2006). The $18 \mathrm{~S}$ rDNA sites in A. hastatus are also minute, and are located at the terminal region of NORbearing chromosomes (Figure 3d-f).

Although sharing these traits in common with most of the previously analyzed Astyanax species, the cytotype B of A. hastatus presented positive signals on both telomeres of an acrocentric pair after FISH experiments with 18S rDNA probes (Figure 3e). The same findings have also been reported in the genera Hoplias (Born and Bertollo, 2000) and Oligosarcus (Hattori et al., 2007), as well as in $A$. scabripinnis (Malacrida et al., 2003; Mantovani et al., 2005) and A. paranae (Vicari et al., 2008), the latter formerly considered as a subspecies of A. scabripinnis. On taking into consideration the high number of populations analyzed so far within the genus Astyanax, bitelomeric NORs cannot be considered as a general trend. At least for the group A. hastatus, they were observed in only one out of the three cytotypes described.

The As-51 satellite DNA is a repetitive DNA sequence formerly identified in $A$. scabripinnis (Mestriner $e t$ al., 2000), and which has also been found in other Astyanax species, thereby representing a useful marker for the genus. The lack of homology with the As-51 satellite DNA observed in A. hastatus (Figure 3g-i) is a characteristic also reported in other species of coastal distribution, such as $A$. giton, A. intermedius (Kavalco et al., 2007) and A. ribeirae (Kavalco KF, PhD Thesis, Universidade de São Paulo, Brazil, 2008). Such a satellite DNA is also absent in $A$. bockmanni (Kavalco et al., 2009), a species from the upper Paraná River basin, and in a population of A. scabripinnis from the São Francisco River (Abel et al., 2006). In relation to the species inhabiting coastal drainage systems, besides the absence of the As-51 satellite DNA, they commonly present several acrocentric chromosomes, remarkably in the karyotypes of $A$. giton and A. intermedius (Kavalco and Moreira-Filho, 2003), the latter displaying a karyotype that is identical to the cytotype $\mathrm{C}$ of $A$. hastatus (Figure 2c). More refined genetic analyses will eventually indicate whether such a resemblance represents a convergence or an ancestral feature of the group. It is worth mentioning that the species found closer to the coast along southeastern Brazil presented a higher number of A chromosomes than those located far from the shore (mainly in the Upper Paraná basin). Perhaps, this trend could reflect a vicariance process, commonly imposed on small-sized fish species (Castro, 1999). Therefore, the coastal populations might have been scattered from a single or few ancestral stocks, the subsequent gene flow constraints among sub-populations leading to their differentiation, to the point of reaching speciation. This would hypothetically explain why those Astyanax species inhabiting coastal areas bear several A chromosomes, whereas Astyanax from other drainages, as for instance $A$. altiparanae, present karyotypes with a higher number of SM chromosomes.

The expression "species complex" refers to those cases where two or more biological species are likely to co-exist, although mutual delimitation is virtually unreachable in the face of their high degree of variation (Nelson, 1999). Although characterization of species based on gene composition is hardly ever accomplishable, the variation observed through cytogenetic studies in Neotropical fishes is likely to reflect the occurrence of cryptic species rather than species complexes, since remarkable differences in chromosomes usually imply unviable crossing. 
Although a correlation between organism and karyotype evolution is not always established, it seems plausible to consider that evolutionary mechanisms might have independently affected each cytotype/species through both particular environmental conditions (i.e., local selective pressure) and the unique genomic features of each cytotype (karyotype formulae, heterochromatin amount and gene location). Such disruptions among distinct evolutionary levels might have been responsible for the occurrence of cryptic fish species, like those detected in Hoplias (Bertollo et al., 1979; Dergam and Bertollo, 1990; Pazza and Julio Jr, 2003), Eigenmannia (Almeida-Toledo et al., 1984, 1985, 1988) and, remarkably, in the genus Astyanax, this including $A$. hastatus. Therefore, the distinct cytotypes herein described should correspond to selection units, thus representing specific entities and composing, not a species complex, but a group of cryptic species, since each cytotype was precisely identified and the biological boundaries among analyzed specimens were supported by the cytogenetic markers used, thereby revealing the lack of hybrid forms. The same form of analysis could also be extended to other species comprising populations of different cytotypes within the genus Astyanax, such as A. scabripinnis, A. fasciatus and A. altiparanae. Although the definition of the term "species complex" might eventually undergo change, as pointed out by Nelson (1999), the terminology "cryptic species" would be suitable for those cases clearly distinguishable through cytogenetic studies.

In spite of striking chromosomal differences and the attempts at morphometric analyses through canonic variables, the subgroups within such cryptic species are not readily differentiated through morphological studies alone (Moreira-Filho and Bertollo, 1991; Maistro et al., 1998; Mizoguchi and Martins-Santos, 1998b; Artoni et al., 2006; Medrado et al., 2008; Pazza et al., 2008; among others). There are two possible explanations for this feature, one that chromosomal preceded morphological modifications, the other that these species present remarkable phenotypic plasticity. Alternatively, it could be claimed that currently performed analyses have simply failed to encounter the existing differences. Taylor (1999) stated that after the development of more sophisticated morphological analyses (e.g., multivariate analysis), most cryptic or sister-species displayed a certain degree of morphological differentiation.

Based on the Darwinian concept or its revisited version (Mallet, 1995), where a species is recognized as a morphological and genotypic cluster, the cytotypes of $A$. hastatus still cannot be referred to as species in themselves. Nevertheless, according to the biological concept of a species, these cytotypes should correspond to real species (Mayr, 1969), since distinct karyotypes have already been found throughout the same hydrographic sub-basin, without any cytogenetic evidence of hybridization events.

\section{Acknowledgments}

The authors wish to thank Luiz R. Malabarba and Vinicius A. Bertaco for taxonomical identification, Carlos E. Lopes for help with the samples, Conselho Nacional de Desenvolvimento Científico e Tecnológico (CNPq) and Fundação de Amparo à Pesquisa do Estado de São Paulo (FAPESP) for financial support.

\section{References}

Abel LDS, Mantovani M and Moreira-Filho O (2006) Chromosomal distribution of the As-51 satellite DNA in two species complexes of the genus Astyanax (Pisces, Characidae). Genet Mol Biol 29:448-452.

Almeida-Toledo LF, Foresti F and Toledo-Filho SA (1984) Complex sex chromosome system in Eigenmannia sp. (Pisces, Gymnotiformes). Genetica 64:165-169.

Almeida-Toledo LF, Foresti F and Toledo-Filho SA (1985) Spontaneous triploidy and NOR activity in Eigenmannia sp. (Pisces, Sternopygidae) from the Amazon basin. Genetica 66:85-88.

Almeida-Toledo LF, Ozouf-Costaz C, Foresti F, Bonillo C, Porto-Foresti F and Daniel-Silva MFZ (2002) Conservation of the 5S-bearing chromosome pair and co-localization with major rDNA clusters in five species of Astyanax (Pisces, Characidae). Cytogenet Genome Res 97:229-233.

Almeida-Toledo LF, Viegas-Péquignot E, Foresti F, Toledo-Filho SA and Dutrillaux B (1988) BrdU replication patterns demonstrating chromosome homeologies in two fish species, genus Eigenmannia. Cytogenet Genome Res 48:117-120.

Artoni RF, Shibatta OA, Gross MC, Schneider CH, Almeida MC, Vicari MR and Bertollo LAC (2006) Astyanax aff. fasciatus Cuvier, 1819 (Teleostei, Characidae): Evidences of a species complex in the upper rio Tibagi basin (Paraná, Brazil). Neotrop Ichthyol 4:1997-2002.

Bertollo LAC, Takahashi CS and Moreira-Filho O (1979) Karyotypic studies of two allopatric populations of the genus Hoplias (Pisces, Erythrinidae). Genet Mol Biol 2:17-37.

Born GG and Bertollo LAC (2000) Comparative cytogenetics among allopatric populations of the fish, Hoplias malabaricus. Cytotypes with $2 \mathrm{n}=42$ chromosomes. Genetica 110:1-9.

Castro RMC (1999) Evolução da ictiofauna de riachos sul-americanos: Padrões gerais e possíveis processos causais. In: Caramashi EP, Mazzoni R and Peres-Neto PR (eds) Ecologia de Peixes de Riachos. PPGE-UFRJ, Rio de Janeiro, pp 139-155.

Daniel-Silva MFZ and Almeida-Toledo LF (2005). Chromosome evolution in fish: BrdU replication patterns demonstrate chromosome homeologies in two species of the genus Astyanax. Cytogenet Genome Res 109:497-501.

Dergam JA and Bertollo LAC (1990) Karyotypic diversification in Hoplias malabaricus (Osteichthyes, Erythrinidae) of the São Francisco and Alto Paraná basins. Genet Mol Biol 13:755-766.

Eigenmann CH (1921) The American Characidae. Memoirs Mus Comp Zool 23:209-310.

Fernandes CA and Martins-Santos IC (2004) Cytogenetic studies in two populations of Astyanax altiparanae (Pisces, Characiformes). Hereditas 141:328-332. 
Ferro DAM, Néo DM, Moreira-Filho O and Bertollo LAC (2001) Nucleolar organizing regions, $18 \mathrm{~S}$ and $5 \mathrm{~S}$ rDNA in Astyanax scabripinnis (Pisces, Characidae): Populations distribution and functional diversity. Genetica 110:55-62.

Gold JR, Li C, Shipley NS and Powers PK (1990) Improved methods for working with fish chromosomes with a review of metaphase chromosome banding. J Fish Biol 37:563-575.

Hatanaka T and Galetti Jr PM (2004) Mapping of the 18S and 5S ribosomal RNA genes in the fish Prochilodus argenteus Agassiz, 1829 (Characiformes, Prochilodontidae). Genetica 122:239-244.

Hattori RS, Daniel-Silva MFZ and Almeida-Toledo LF (2007) Karyotype characterization and gene mapping of $5 \mathrm{~S}$ and $18 \mathrm{~S}$ rDNA in three species of Oligosarcus (Teleostei, Characidae). Caryologia 60:372-378.

Jeffery WR (2001) Cavefish as a model system in evolutionary developmental biology. Dev Biol 231:1-12.

Kavalco KF and Moreira-Filho O (2003) Cytogenetical analyses in four species of the genus Astyanax (Pisces, Characidae) from Paraíba do Sul river basin. Caryologia 56:453-461.

Kavalco KF and Pazza R (2004) A rapid alternative technique for obtaining silver-positive patterns in chromosomes. Genet Mol Biol 27:196-198.

Kavalco KF, Pazza R, Bertollo LAC and Moreira-Filho O (2007) Satellite DNA sites of four species of the genus Astyanax (Teleostei, Characiformes). Genet Mol Biol 30:329-335.

Kavalco KF, Pazza R and Almeida-Toledo LF (2009) Astyanax bockmanni Vari and Castro, 2007: An ambiguous karyotype in the Astyanax genus. Genetica 136:135-139.

Langecker TG, Wilkens H and Junge P (1991) Introgressive hybridization in the Pachon cave population of Astyanax fasciatus. Ichthyol Explor Freshw 2:209-212.

Levan A, Fredga K and Sandberg AA (1964) Nomenclature for centromeric position on chromosomes. Hereditas 52:201220.

Maistro EL, Oliveira C and Foresti F (1998) Comparative cytogenetic and morphological analysis of Astyanax scabripinnis paranae (Pisces, Characidae, Tetragonopterinae). Genet Mol Biol 21:201-206.

Malacrida ACCP, Dias AL and Giuliano-Caetano L (2003) Natural triploidy in Astyanax aff. scabripinnis (Pisces, Characidae) of the Tibagi river basin-PR. Cytologia 68:267-270.

Mallet J (1995) A species definition for the modern synthesis. Trends Ecol Evol 10:294-299.

Mantovani M, Abel LDS and Moreira-Filho O (2005) Conserved $5 \mathrm{~S}$ and variable $45 \mathrm{~S}$ rDNA chromosomal localization revealed by FISH in Astyanax scabripinnis (Pisces, Characidae). Genetica 123:211-216.

Mayr E (1969) The biological meaning of species. Biol J Linnean Soc 1:311-320.

Medrado AS, Figueiredo AVA, Waldschmidt AM, Affonso PRAM and Carneiro PLS (2008) Cytogenetic and morphological diversity in populations of Astyanax fasciatus
(Teleostei, Characidae) from Brazilian northeastern river basins. Genet Mol Biol 31:208-214.

Mestriner CA, Galetti Jr PM, Valentini SR, Ruiz IRG, Abel LDS, Moreira-Filho O and Camacho JPM (2000) Structural and functional evidence that a $\mathrm{B}$ chromosome in the characid fish Astyanax scabripinnis is an isochromosome. Heredity 85:1-9.

Mizoguchi SMHN and Martins-Santos IC (1998) Cytogenetic and morphometric differences in populations of Astyanax "scabripinnis" (Pisces Characidae) from Maringá region, PR, Brazil. Genet Mol Biol 21:55-61.

Moreira-Filho O and Bertollo LAC (1991) Astyanax scabripinnis (Pisces, Characidae): A species complex. Genet Mol Biol 14:331-357.

Nelson JC (1999) Editorial and introduction: The species concept in fish biology. Rev Fish Biol Fisheries 9:277-280.

Pazza R and Julio Jr HF (2003) Occurrence of three sympatric cytotypes of Hoplias malabaricus (Pisces, Erythrinidae) in the upper Paraná river foodplain (Brazil). Cytologia 68:159-163.

Pazza R and Kavalco KF (2007) Chromosomal evolution in the neotropical characin Astyanax (Teleostei, Characidae). Nucleus 50:519-543.

Pazza R, Kavalco KF and Bertollo LAC (2006) Chromosome Polymorphism in Astyanax fasciatus (Teleostei, Characidae). 1 - Karyotypic analysis, Ag-NORs and mapping of the $18 \mathrm{~S}$ and $5 \mathrm{~S}$ ribosomal genes in sympatric karyotypes and their possible hybrid forms. Cytogenet Genome Res 112:313-319.

Pazza R, Kavalco KF, Prioli SMAP, Prioli AJ and Bertollo LAC (2007) Chromosome polymorphism in Astyanax fasciatus (Teleostei, Characidae). 3: Analysis of the RAPD and ISSR molecular markers. Biochem Syst Ecol 35:843-851.

Pazza R, Kavalco SAF, Penteado PR, Kavalco KF and AlmeidaToledo LF (2008) The species complex Astyanax fasciatus Cuvier, 1819 (Teleostei, Characiformes): A multidisciplinary approach. J Fish Biol 72:2002-2010.

Pinkel D, Straume T and Gray JW (1986) Cytogenetic analysis using quantitative, high-sensitivity, fluorescence hybridization. Proc Natl Acad Sci USA 83:2934-2938.

Sumner AT (1972) A simple technique for demonstrating centromeric heterocromatin. Exp Cell Res 75:304-306.

Taylor EB (1999) Species pairs of north temperate freshwater fishes: Evolution, taxonomy and conservation. Rev Fish Biol Fisheries 9:299-324.

Vicari MR, Noleto RB, Artoni RF, Moreira-Filho O and Bertollo LAC (2008) Comparative cytogenetics among species of the Astyanax scabripinnis complex. Evolutionary and biogeographical inferences. Genet Mol Biol 31:173-179.

\section{Associate Editor: Yatiyo Yonenaga-Yassuda}

License information: This is an open-access article distributed under the terms of the Creative Commons Attribution License, which permits unrestricted use, distribution, and reproduction in any medium, provided the original work is properly cited. 